\title{
PERAN DISIPLIN KERJA SEBAGAI MODERATOR DALAM HUBUNGAN ANTARA BEBAN KERJA DENGAN KINERJA
}

\author{
Ferry Sataputera \\ Program Studi Magister Manajemen Universitas Tarumanagara \\ ferry.117191053@stu.untar.ac.id \\ Rostiana \\ Program Studi Magister Manajemen Universitas Tarumanagara
}

Masuk : 08-12-2020, revisi : 21-12-2020, diterima untuk diterbitkan : 22-12-2020

\begin{abstract}
This study aims to analyze the role of work discipline as a moderator in the relationship between workload and performance at PT X. The data source was obtained from distributing questionnaires to 100 production employees at PT X. The sampling technique used is a convenience sampling approach. The analytical method used in this research is the Partial Least Square Regression method using SMART PLS 3.0 software. The results of the analysis show that there is a negative and significant relationship between workload and employee performance. This relationship is weakened by the work discipline variable as a moderating variable.
\end{abstract}

Keywords: Work Discipline, Workload, Performance

Abstrak: Penelitian ini bertujuan untuk menganalisis peran disiplin kerja sebagai moderator dalam hubungan antara beban kerja dengan kinerja pada PT X. Sumber data diperoleh dari penyebaran kuesioner kepada 100 orang karyawan bagian produksi di PT X. Teknik sampling yang digunakan adalah dengan pendekatan convenience sampling. Metode analisis yang digunakan dalam penelitian ini adalah metode Partial Least Square Regression dengan menggunakan software SMARTPLS 3.0. Hasil analisis menunjukkan adanya hubungan yang negatif dan signifikan antara beban kerja dengan kinerja karyawan. Hubungan ini diperlemah dengan variabel disiplin kerja sebagai variabel moderasi.

Kata Kunci: Disiplin Kerja, Beban Kerja, Kinerja

\section{PENDAHULUAN}

Sumber daya manusia adalah aset yang paling penting bagi keberlangsungan masa depan perusahaan (Usman \& Akbar, 2009), sehingga manajemen sumber daya menjadi hal yang harus diperhatikan untuk dapat meningkatkan kinerja perusahaan secara keseluruhan. Dengan persaingan yang semakin ketat, banyak perusahaan yang berusaha untuk meningkatkan efisiensi. Salah satu cara yang dilakukan adalah dengan meminimalisasi jumlah karyawan. Kurangnya jumlah karyawan terkadang bukan meningkatkan kinerja, tetapi menurunkan kinerja perusahaan. Hal ini didukung oleh penelitian yang dilakukan oleh Jamal (2007), Diana (2019), Zebua (2020), Rolos et al. (2018), dan Shah et al. (2011) yang menemukan bahwa beban kerja yang tinggi membuat karyawan sulit untuk fokus bekerja dan menurunkan kinerja dari karyawan itu sendiri. Namun penelitian yang dilakukan oleh Permatasari et al. (2019), Khasifah dan Nugraheni (2016), Chandra dan Adriansyah (2017) menemukan bahwa beban kerja tidak memberikan pengaruh kepada kinerja.

Selain beban kerja, faktor lain yang memberikan pengaruh terhadap kinerja karyawan adalah disiplin kerja (Hendrawan et al., 2017; Heriyanto \& Hidayati, 2016; Husain, 2017; Safitri, 2013; Sulaefi, 2017), seperti tingkat absensi, serta datang dan pulang kerja tepat pada waktunya (Khasifah \& Nugraheni, 2016). Pengaruh beban kerja terhadap kinerja karyawan 
juga masih menjadi perdebatan. Basuki dan Saputra (2017) dan Permatasari et al. (2019) menemukan bahwa disiplin kerja tidak berpengaruh kepada kinerja karyawan.

Oleh karena pro dan kontra ini maka peneliti akan melakukan penelitian mengenai pengaruh beban kerja serta disiplin kerja terhadap kinerja. Penelitian ini akan melihat dari sudut pandang yang berbeda dengan penelitian terdahulu, yaitu dengan menggunakan variabel disiplin menjadi moderator antara hubungan beban kerja dengan kinerja karyawan. Jadi penelitian ini akan berkontribusi untuk memperkaya studi literatur dalam pengelolaan sumber daya manusia untuk dapat memaksimalkan kinerja perusahaan. Namun terdapat pula penelitian yang tidak sejalan, antara lain Basuki dan Saputra (2017) yang menemukan bahwa disiplin kerja tidak memediasi pengaruh sistem reward terhadap kinerja karyawan, dan Permatasari et al. (2019) yang menemukan bahwa disiplin kerja tidak berpengaruh terhadap kinerja pegawai.

\section{Tujuan Penelitian}

Tujuan dari penelitian ini adalah:

1. Untuk mencari tahu apakah beban kerja yang tinggi memberikan pengaruh terhadap kinerja karyawan.

2. Untuk mengetahui apakah beban kerja yang tinggi memberikan pengaruh yang cukup signifikan terhadap kinerja pada saat disiplin kerja juga tinggi.

\section{TINJAUAN PUSTAKA \\ Beban Kerja}

Menurut Tarwaka (2014), definisi beban kerja adalah perbedaan antara kapasitas atau kemampuan pekerja dengan tuntutan pekerjaan yang harus dihadapi. Dalam setiap pekerjaan yang dilakukan karyawan memiliki tingkat pembebanan yang bervariasi. Sedangkan dalam Permendagri No. 12 Tahun 2008 (Mendagri, 2008), beban kerja adalah besaran pekerjaan yang harus dipikul oleh suatu jabatan atau unit organisasi dan merupakan hasil kali antara volume kerja dan norma waktu. Menurut Koesomowidjojo (2017), terdapat 2 (dua) jenis beban kerja yaitu: beban kerja kuantitatif dan beban kerja kualitatif. Selain itu Arsi dan Pratiwi (2012) membuat kategori nilai beban kerja berdasarkan waktu.

Terdapat 2 (dua) faktor yang mempengaruhi beban kerja, antara lain: faktor internal (seperti: jenis kelamin, usia, postur tubuh, status kesehatan), dan faktor eksternal (seperti: lingkungan kerja, tugas-tugas fisik, organisasi kerja) (Koesomowidjojo, 2017). Di sisi lain, Gibson et al. (1995) menyatakan bahwa beban kerja dipengaruhi oleh tekanan waktu, jadwal dan jam kerja, konflik peran, kebisingan, informasi berlebih, panas berlebih, dan pekerjaan yang berulang.

Menurut Shah et al. (2011), salah satu faktor yang dapat mempengaruhi kinerja karyawan adalah beban kerja. Ketika beban kerja tinggi maka bisa memberikan peningkatan produktivitas (Jamal, 2007), namun pada saat beban kerja terlalu tinggi maka akan berdampak ke penurunan tingkat produktivitas. Hal tersebut juga di dukung dengan penelitian sebelumnya yang dilakukan oleh Johari et al. (2018), Paramitadewi (2017), dan Sutoyo (2016) yang menemukan bahwa beban kerja berpengaruh negative dan signifikan terhadap variabel kinerja pegawai. Namun ditemukan pula beberapa penelitian yang tidak sejalan. Menurut Chandra dan Adriansyah (2017), meskipun beban kerja yang tinggi memberikan pengaruh negatif terhadap kinerja, tetapi hubungan tersebut tidaklah signifikan. Penelitian Khasifah dan Nugraheni (2016) juga menemukan hal yang berbeda, dimana ditemukan adanya pengaruh yang positif antara beban kerja dengan kinerja meskipun hubungan tersebut tidak signifikan. Permatasari et al. (2019) bahkan menyatakan bahwa beban kerja tidak berdapak pada peningkatan dan penurunan dari kinerja karyawan.

\section{Disiplin Kerja}

Selain beban pekerjaan, faktor lain yang juga diduga memberikan pengaruh terhadap kinerja karyawan adalah disiplin kerja seperti tingkat absensi serta datang dan pulang kerja tepat pada waktunya (Khasifah \& Nugraheni, 2016). Kedisiplinan adalah kesadaran dan 
kesediaan seseorang mentaati semua peraturan-peraturan perusahaan dan norma yang berlaku (Hasibuan, 2012) dengan disertai kesadaran diri (Thaief et al., 2015).

Terdapat banyak indikator yang mempengaruhi tingkat kedisiplinan pegawai, diantaranya adalah tujuan dan kemampuan, teladan pimpinan, balas jasa, keadilan, waskat (pengawasan melekat), sanksi hukum, ketegasan, dan hubungan kemanusiaan (Hasibuan, 2012). Rivai (2014) mengemukakan bahwa terdapat 5 (lima) komponen dalam kedisiplinan kerja, antara lain: kehadiran, ketaatan pada peraturan kerja, ketaatan pada standar kerja, tingkat kewaspadaan tinggi, dan etika bekerja. Dimana menurut Luthans (2006), disiplin kerja dapat timbul dari diri sendiri maupun perintah.

Hubungan pengaruh antara disiplin kerja dan kinerja juga telah diteliti sebelumnya dengan hasil yang berbeda-beda. Menurut Khasifah dan Nugraheni (2016), disiplin kerja akan memberikan pengaruh yang positif dan signifikan terhadap kinerja karyawan. Hal ini juga didukung oleh penelitian yang dilakukan oleh Sari dan Hadijah (2016), yang menyatakan bahwa disiplin kerja merupakan salah satu faktor yang berpengaruh terhadap kinerja. Bahkan disiplin kerja juga terbukti positif dan signifikan sebagai intervening hubungan antara motivasi, kepuasan kerja dan kinerja (Hendrawan et al., 2017).

\section{METODOLOGI PENELITIAN}

Jenis penelitian yang digunakan penulis untuk penelitian ini adalah penelitian kuantitatif dengan bentuk penelitian eksplanatori untuk membuktikan "peran disiplin sebagai moderator dalam hubungan antara beban kerja dan kinerja."

Populasi dalam penelitian ini adalah karyawan PT X yang berjumlah 132 orang. Dari keseluruhan karyawan yang menjadi populasi, sampel dipilih dengan pendekatan convenience sampling karena kumpulan informasi yang diperoleh yang diberikan kepada 132 orang karyawan, hanya 100 orang yang berasal dari karyawan bagian produksi saja yang bisa digunakan sebagai sumber data untuk dianalisa.

Metode analisis yang digunakan dalam penelitian ini adalah metode Partial Least Square Regression dengan menggunakan bantuan program SMARTPLS 3.0 untuk melihat pengaruh moderasi dari variabel Disiplin dalam hubungan antara variabel beban kerja terhadap kinerja.

\section{HASIL PENELITIAN \\ Karakteristik Responden}

Profil responden dikategorikan berdasarkan jenis kelamin, usia, tingkat pendidikan level jabatan, serta lama bekerja. Berdasarkan jenis kelamin, responden berjenis kelamin pria berjumlah 38 orang (38\%) dan responden yang berjenis kelamin wanita berjumlah 62 orang (62\%). Sedangkan bedasarkan umur, didominasi dengan usia 30-40 tahun sebanyak 63 orang (63\%), diikuti dengan rentang usia 20-30 tahun berjumlah 23 orang (23\%), dan usia 40-50 tahun berjumlah 14 orang $(14 \%)$. Berdasarkan pendidikan, responden terbanyak memiliki tingkat pendidikan SMA dan sederajat dengan jumlah responden sebanyak 74 orang (74\%), diikuti dengan lulusan D3 sejumlah 21 orang (21\%) dan S1 sejumlah 5 orang (5\%). Kategori yang keempat adalah level jabatan. Responden pada penelitian ini didominasi oleh operator produksi sebanyak 95 orang (95\%), dan sisanya adalah leader produksi berjumlah 2 orang (2\%), supervisor produksi berjumlah 2 orang (2\%) dan manager produksi berjumlah 1 orang $(1 \%)$. Karakteristik yang terakhir adalah berdasarkan lama bekerja. Responden yang bekerja antara 1 -3 tahun berjumlah 15 orang (15\%), antara 3 - 5 tahun berjumlah 53 orang (53\%) dan diatas 5 tahun berjumlah 14 orang (14\%). 


\section{Hasil Uji Hipotesis}

Tabel 1 menunjukkan hasil pengukuran untuk melihat hubungan antar variabel laten.

\section{Tabel 1}

Hasil Uji Hipotesis

\begin{tabular}{cccccc}
\hline & $\begin{array}{c}\text { Original Sample } \\
(\boldsymbol{O})\end{array}$ & $\begin{array}{c}\text { Sample Mean } \\
(\boldsymbol{M})\end{array}$ & $\begin{array}{c}\text { Standard } \\
\text { Deviation }\end{array}$ & $\begin{array}{c}\boldsymbol{T} \text { - } \\
\text { Statistics }\end{array}$ & $\begin{array}{c}\boldsymbol{P} \text { - } \\
\text { Values }\end{array}$ \\
\hline Beban Kerja $\rightarrow$ Kinerja & $-0,617$ & $-0,618$ & 0,049 & 12,461 & 0,000 \\
Disiplin $\rightarrow$ Kinerja & 0,483 & 0,481 & 0,048 & 10,142 & 0,000 \\
Moderating Effect 1 $\rightarrow$ & $-0,137$ & $-0,135$ & 0,030 & 4,549 & 0,000 \\
Kinerja & & &
\end{tabular}

Sumber: Data diolah Penulis (2020)

Seperti yang terlihat pada Tabel 1, nilai koefisien jalur hipotesis (H1) adalah -0,617 dengan P-Value sebesar 0,000 (lebih kecil dari 0.05), hal ini berarti terdapat hubungan negatif dan signifikan antara variabel Beban Kerja terhadap Kinerja. Sedangkan nilai koefisien jalur hipotesis (H2) adalah 0,483 dengan P-Value sebesar 0,000, hal ini berarti terdapat hubungan yang positif dan signifikan antara variabel Disiplin kerja terhadap Kinerja. Tingkat signifikansi juga terlihat dari nilai T-statistik, dimana $\mathrm{H} 1$ dan $\mathrm{H} 2$ memiliki nilai $\mathrm{T}$-statistik diatas $\mathrm{T}$-tabel (Sig 95\%) dengan nilai 1,96. Selain itu, karena nilai koefisien jalur dari moderating efek adalah 0.137 dengan P-Value sebesar 0,000 dan T-statistik sebesar 4,549; maka dapat disimpulkan bahwa Disiplin memperlemah hubungan antara Beban Kerja dengan Kinerja Karyawan.

\section{Tabel 2}

Koefisien Determinasi (R-Square)

\begin{tabular}{cc}
\hline & R-square \\
\hline Kinerja & 0,686 \\
\hline
\end{tabular}

Sumber: Data diolah Penulis (2020)

Tabel 2 menunjukkan hasil nilai R-square variabel kinerja sebesar 0,686. Hal ini dapat diinterpretasikan bahwa kemampuan variabel independen yaitu Beban Kerja dan Disiplin untuk memberikan pengaruh ke variabel konstruk Kinerja adalah sebesar 68,6\% sedangkan $31,4 \%$ dipengaruhi oleh faktor lain yang tidak diteliti dalam penelitian ini.

\section{KESIMPULAN}

Jadi berdasarkan penelitian ini dapat disimpulkan bahwa beban kerja yang tinggi memberikan pengaruh yang negatif dan signifikan terhadap kinerja, dan disiplin yang baik dapat memperlemah hubungan negatif antara beban kerja dengan kinerja. Jadi sangatlah penting bagi perusahaan untuk memperhatikan beban kerja setiap karyawannya agar bisa mencapai tingkat efisiensi yang terbaik. Selain beban kerja, faktor disiplin juga perlu diperhatikan melalui kebijakan-kebijakan yang ditunjukan untuk dapat meningkatkan disiplin karyawan. Penelitian ini masih dapat dikembangkan di masa yang akan datang dengan memperbanyak jumlah responden, serta menambahkan faktor-faktor lain yang dapat mempengaruhi kinerja karyawan.

\section{DAFTAR PUSTAKA}

Arsi, R. M., \& Partiwi, S. G. (2012). Analisis beban kerja untuk menentukan jumlah optimal karyawan dan pemetaan kompetensi karyawan berdasar pada job description (Studi kasus: Jurusan Teknik Industri, ITS, Surabaya). Teknis ITS, 1(1), 526-529. https://doi.org/10.12962/j23373539.v1i1.1824

Basuki, K., \& Saputra, G. A. (2017). Pengaruh lingkungan kerja dan sistem reward terhadap kinerja karyawan di moderasi disiplin kerja (Studi pada PT. Mitra Inovasi Gemilang) di Jakarta. Jurnal Online Internasional \& Nasional, 4(1), 92-108. http://journal.uta45jakarta.ac.id/index.php/MMJ/article/view/714/430 
Chandra, R., \& Adriansyah, D. (2017). Pengaruh beban kerja dan stres kerja terhadap kinerja karyawan pada PT. Mega Auto Central Finance Cabang di Langsa. Jurnal Manajemen Dan Keuangan, 6(1), 670-678. http://jurnal.unsam.ac.id/index.php/jmk/article/view/214/167

Diana, Y. (2019). Pengaruh beban kerja terhadap kinerja karyawan di Housekeeping Department pada Hotel Bintan Lagoon Resort. Jurnal Manajemen Tools, 11(2), 193205. https://jurnal.pancabudi.ac.id/index.php/JUMANT/article/view/704/667

Hasibuan, M. S. P. (2012). Manajemen sumber daya manusia. PT Bumi Aksara.

Hendrawan, A., Pradhanawati, A., \& Ngatno. (2017). Pengaruh motivasi kerja dan kepuasan kerja terhadap kinerja karyawan melalui disiplin kerja sebagai variabel intervening. Jurnal Ilmu Administrasi Bisnis, 6(1), 357-367. https://ejournal3.undip.ac.id/index.php/jiab/article/view/14617/14141

Heriyanto, \& Hidayati, S. N. (2016). Pengaruh motivasi kerja dan disiplin kerja terhadap kinerja pegawai. Jurnal Maksipreneur: Manajemen, Koperasi, Dan Entrepreneurship, 6(1), 67-76. https://doi.org/10.30588/jmp.v6i1.285

Husain, B. A. (2017). Pengaruh disiplin kerja terhadap kinerja karyawan (Pada PT. Bank Danamon Tbk Cabang Bintaro). JENIUS (Jurnal Ilmiah Manajemen Sumber Daya Manusia), 1(1), 65-73. https://doi.org/10.32493/jjsdm.v1i1.655

Jamal, M. (2007). Job stress and job performance controversy revisited: An empirical examination in two countries. International Journal of Stress Management, 14(2), 175187. https://doi.org/10.1037/1072-5245.14.2.175

James L. Gibson, Ivancevich, J. M., \& Donnelly, J. H. (1995). Organisasi (5th ed.). Erlangga.

Johari, J., Yean Tan, F., \& Tjik Zulkarnain, Z. I. (2018). Autonomy, workload, work-life balance and job performance among teachers. International Journal of Educational Management, 32(1), 107-120. https://doi.org/10.1108/IJEM-10-2016-0226

Khasifah, F., \& Nugraheni, R. (2016). Pengaruh disiplin kerja, beban kerja, dan lingkungan kerja terhadap kinerja pegawai (Studi pada Balai Besar Wilayah Sungai Pemali Juana). Diponegoro Journal of Management, 5(1), 334-340. https://ejournal3.undip.ac.id/index.php/djom/article/view/13471/13027

Koesomowidjojo, S. R. M. (2017). Panduan praktis menyusun analisis beban kerja. Raih Asa Sukses.

Luthans, F. (2006). Perilaku organisasi (10th ed.). Andi.

Mendagri. (2008). Permendagri No. 12 Tahun 2008 tentang pedoman analisis beban kerja di lingkungan departemen dalam negeri dan pemerintah daerah.

https://jatim.kemenag.go.id/file/file/peraturantentangPNS/hnwi1425872320.pdf

Paramitadewi, K. F. (2017). Pengaruh beban kerja dan kompensasi terhadap kinerja pegawai Sekretariat Pemerintah Daerah Kabupaten Tabanan. E-Jurnal Manajemen Universitas Udayana, 6(6), 3370-3397.

https://ojs.unud.ac.id/index.php/Manajemen/article/view/29949/18950

Permatasari, D., Sufian, S., \& Rachmansyah, Y. (2019). Analisis pengaruh motivasi kerja, kompetensi dan beban kerja terhadap kinerja pegawai dengan disiplin kerja sebagai variabel moderasi (Studi empiris pada pengurus barang di lingkungan Pemerintah Kota Semarang). Magisma: Jurnal Ilmiah Ekonomi Dan Bisnis, 7(1), 19-34. https://doi.org/10.35829/magisma.v7i1.37

Rivai, V. (2014). Manajemen sumber daya manusia untuk perusahaan (6th ed.). PT Raja Grafinfo Persada.

Rolos, J., Sambul, S., \& Rumawas, W. (2018). Pengaruh beban kerja terhadap kinerja karyawan pada PT. Asuransi Jiwasraya Cabang Manado. Jurnal Administrasi Bisnis, 6(4), 19-27. https://doi.org/10.35797/jab.6.004.2018.21074.19-27 
Safitri, E. (2013). Pengaruh pelatihan dan disiplin kerja terhadap kinerja karyawan. Jurnal Ilmu Manajemen (JIM), 1(4), 1044-1054. https://jurnalmahasiswa.unesa.ac.id/index.php/jim/article/view/6262/7114

Sari, R. N. I., \& Hadijah, H. S. (2016). Peningkatan kinerja pegawai melalui kepuasan kerja dan disiplin kerja. Jurnal Pendidikan Manajemen Perkantoran, 1(1), 204. https://doi.org/10.17509/jpm.v1i1.3389

Shah, S. S. H., Jaffari, A. R., Aziz, J., Ejaz, W., Ul-Haq, I., \& Raza, S. N. (2011). Workload and performance of employees. Interdisciplinary Journal of Contemporary Research In Business, 3(5), 256-267. https://journal-archieves8.webs.com/256-267.pdf

Sulaefi. (2017). Motivasi terhadap kinerja karyawan dengan kepuasan dan disiplin kerja sebagai variabel mediasi pada Dinas Pertanian dan Ketahanan Pangan, Kabupaten Tegal. Jurnal Analisis Bisnis Ekonomi, 15(1), 20-30. https://doi.org/10.31603/bisnisekonomi.v15i1.1001

Sutoyo. (2016). Pengaruh beban kerja, lingkungan kerja dan motivasi terhadap kinerja pegawai pada Dinas Bina Marga Provinsi Sulawesi Tengah. Katalogis, 4(3), 187-195. http://jurnal.untad.ac.id/jurnal/index.php/Katalogis/article/view/6565

Tarwaka. (2014). Ergonomi industri: Dasar-dasar pengetahuan ergonomi dan aplikasi di tempat kerja (2nd ed.). Harapan Press.

Thaief, I., Baharuddin, A., Priyono, \& Idrus, M. S. (2015). Effect of training, compensation and work discipline against employee job performance (Studies in the office of PT. PLN (Persero) Service Area and Network Malang). Review of European Studies, 7(11), 2333. https://doi.org/10.5539/res.v7n11p23

Usman, H., \& Akbar, P. S. (2009). Metodologi penelitian sosial. Bumi Aksara.

Zebua, Y. (2020). Pengaruh disiplin kerja dan beban kerja terhadap kinerja pegawai pada Dinas Pertanian Kab. Labuhan Batu Utara. Jurnal Ekonomi Bisnis Dan Manajemen Akuntansi, 1(1), 107-116. https://doi.org/10.36987/ebma.v1i1.1904 